\title{
Comparative Analysis of the Flora of the Ketpen-Temerlik in Kazakhstan and China (Northern Tian Shan)
}

\section{Gulbanu Sadyrova ${ }^{1 *}$, Gani Sadyrov², Saule Zhamilova ${ }^{3}$, Nursulu Jusupbekova ${ }^{3}$, Duman Baizhygitov ${ }^{3}$, Marzhan Dauletbaeva', Aigul Urymbayeva'}

\author{
1 Al-Farabi Kazakh National University, Almaty, Republic of Kazakhstan \\ 2 Kazakh National Women's Teacher Training University, Almaty, Republic of Kazakhstan \\ 3 Abai Kazakh National Pedagogical University, Almaty, Republic of Kazakhstan \\ * Correspondinfg author's e-mail: gulbanu.sadyrova@bk.ru
}

\begin{abstract}
The article provides a comparative analysis of the flora and endemism of the western and eastern part of the KetpenTemerlik range in Kazakhstan and China, which is the eastern tip of the Northern Tian Shan. The flora of the entire Ketpen-Temerlik range includes 1890 species of vascular plants belonging to 593 genera and 120 families. In the western part of the ridge (in Kazakhstan), 1747 species were identified, belonging to 585 genera and 111 families and in the eastern part (in China), 1673 species belonging to 577 genera and 117 families. Angiosperms make up $98.4 \%$ of the ridge flora, $80.0 \%$ of which are dicotyledonous and $18.5 \%$ are monocotyledonous. The analysis of the largest flora families of the entire Ketpen-Temerlik range allowed us to identify 28 of the largest families by the largest number of species. The families with the largest number of species are Asteraceae (308 species), Poaceae (166), Fabaceae (133), Brassicaceae (105), Caryophyllaceae (93), Rosaceae (90), Lamiaceae (81), Chenopodiaceae (75), Ranunculaceae (74) and Scrophulariaceae (57). The major genera are Astragalus (43 species), Artemisia (38), Taraxacum (34), Carex (33), Allium (33), Potentilla (31), Ranunculus (22), Oxytropis (21), Veronica (20), Poa (18), and Saussurea (18).
\end{abstract}

Keywords: Kazakhstan, China, flora, North Tian-Shan, Ketpen, Temerlik.

\section{INTRODUCTION}

The Ketpen-Temerlik range is located in the desert zone of the Northern Tian Shan on the territory of two countries - Kazakhstan and China. The eastern part of the range located in Kazakhstan is called Ketpen and the western part in China, is called Temerlik. The Ketpen-Temerlik range is a mountainous region which is clearly delineated geographically and historically and has a rich flora which differs from the floras of the adjacent regions (Dzhungarian Alatau, Central and Western Tian Shan) with a concentration of relict elements representing different times, different genesis, and different histories. A thorough floristic study of the Ketpen-Temerlik range allowed us to form a complete picture of the general development of the mountain flora of the range. The relevance of the floristic study of the mountainous areas of the Northern Tien Shan with the aim of preserving biodiversity and endemism is related to the fact that the flora of the KetpenTemerlik range located in Kazakhstan and China has been practically unexplored until today. Additionally, the excessive and prolonged exploitation of mountain pastures in some cases has led to irreversible changes in the pristine biocenosis, the reduction of habitats and the disappearance of rare plant species in this ridge. For the first time, a comparative analysis of the flora of the western and eastern parts of the Ketpen-Temerlik range in Kazakhstan and China revealed the peculiarities of its heterogeneous flora, the formation of which resulted from the impact of various floristic concentrations and different time periods involving formation of individual taxa, as well as the effects of deserts in Central Asia. The flora of the Ketpen-Temerlik range includes the endemic and 
rare plant species of considerable scientific interest. The identification of rare and endangered species of the studied flora, the identification of their habitat boundaries, and their protection in order to preserve the natural gene pool are now becoming increasingly important and relevant.

\section{MATERIALS AND METHODS}

The main methods of research for endangered rare, endemic and subendemic plant species of the Ketpen-Temerlik range were the generally accepted classical methods of botanical and floristic research and traditional methods of geobotanical research, the traditional routereconnaissance method was used in the field. In the process of determining the herbarium, multivolume reports were used as sources: "Flora of the USSR" [1934-1964], "Flora of Kazakhstan" [1956-1966], "Plants of Central Asia" [1963-1989], "Guide to the Plants of Central Asia" [1968-1993], "Illustrated Guide to Plants in Kazakhstan " [1962-1975], "Flora of China" [1994, 2003], "Flora Xinjiangensis" [1992-2004] and others. In order to clarify the species and generic names, the latest reports of S.K. Cherepanov, S.A. Abdulina[Cherepanov, 1995; Abdulina, 1998] were used. When justifying the relictism of individual rare, endemic and subendemic plant species of the Ketpen ridge, the scientific works of a number of authors were taken into account, including: M.S. Baitenov, A.I., Bykov, N.V. Rubtsov and others [Rubtsov, 1948; Baitenov, 1985; Bykov, 1979].

\section{RESULTS}

The material for this study consists of the collections gathered by the authors during field expeditions and observations from 2003 to 2017. More than 25 floristic expeditions were conducted along the Ketpen-Temerlik range in Kazakhstan and China (Figure 1).

The researched Ketpen-Temerlik range belongs to the Northern Tian Shan system, being its most eastern extremity. The length of the whole ridge is more than $400 \mathrm{~km}$, and the width is $40-50 \mathrm{~km}$. The Ketpen-Temerlik range is located between $44^{\circ} 00^{\prime} \mathrm{N} 79^{\circ} 30^{\prime} \mathrm{E}$ and $43^{\circ} 20^{\prime} \mathrm{N}$ $85^{\circ} 00^{\prime} \mathrm{E}$.

According to the physical-geographical zoning of Kazakhstan [Chupakhin, 1970], the Ketpen range is in the Central Asian country, the Tian Shan region, the North Tian Shan province, Chilik-Ketpen district and two regions: the northern slope of the Ketpen ridge and Kegen-Tekes region (Figure 2).

The highest peak of the Ketpen-Temerlik range is $3680 \mathrm{~m}$ high and located in the eastern part near the border with China (mountain
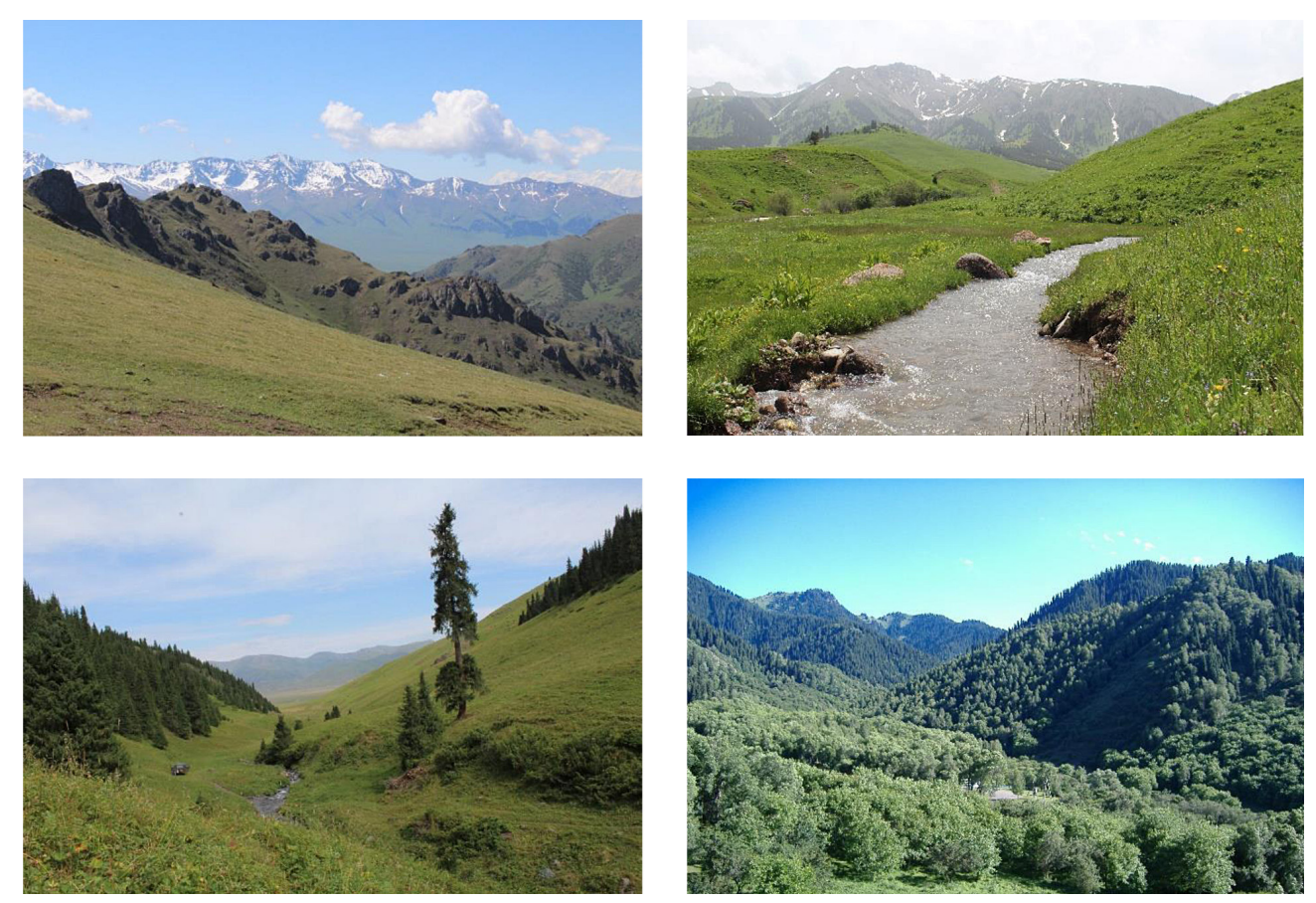

Figure 1. The Ketpen-Temerlik ridge in Kazakhstan and China 


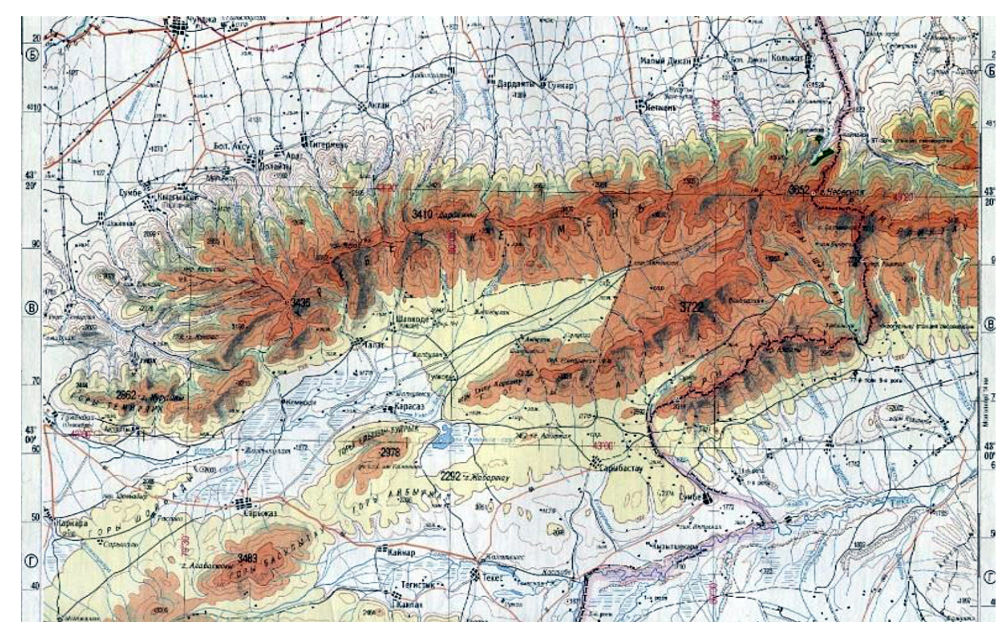

Figure 2. Map of the Ketpen range

Podnebesnaya); it gradually decreases to $3400 \mathrm{~m}$ to the west. The peaks of the mountains do not reach the snow line and have no glaciers. In Kazakhstan, the Ketpen ridge borders by the Dzungar Alatau in the north, which is divided by the Ili depression; in the west with the Kungey Alatau; in the east, the Ketpen range gradually passes into the Temerlik range, where it merges with the Borohoro range. In China, the eastern part of the Ketpen range continues under the name of the Temerlik, where it further goes into the Borohoro mountain range [Atlas of the Kazakh SSR. Natural conditions and resources, 1982].

\section{Analysis of the flora of the Ketpen-Temerlik range}

When analyzing the flora of the Ketpen-Temerlik range, the authors used the "concrete flora" which represents the elementary natural flora at the regional level. Each of the concrete floras has a specific species composition and differs from the others within the same sub-province, as a rule, by less common species (endemic, relict, rare at the distribution border) [Pavlov, 1959; Yurtsev, 2000; Malyshev, 1972; Gellie, 2005; Moreno et al., 2018; Chen et al., 2009; Chang et al. 2012].

The comparison of floras is one of the most important aspects of the floristic research. A comparative analysis contributes to the establishment of sources and formation of this flora, the identification of its specific features determined by the modern natural conditions of the area and the characteristics of the course of florogenesis. Additionally, comparative floristic studies enable to identify the geographical patterns of changes in the composition and structure of floras [Malyshev,
1972]. The authors investigated specific (elementary) flora in the western and eastern part of the Ketpen-Temerlik range in two countries - Kazakhstan and China.

A detailed floristic analysis of two specific flora of the Ketpen-Temerlik ridge with a total area of $20,925 \mathrm{~km}^{2}$, our field studies, as well as a generalization of all available literature data on the topic, revealed 1890 species of vascular plants belonging to 593 genera and 120 families, which is $63.0 \%$ of the total flora of the Northern Tien Shan, numbering 3000 species [Rubtsov, 1948].

The quantitative characteristics of the flora and, above all, the richness of its species are the most important indicators demonstrating the degree of heterogeneity in the flora's territory, the diversity of the physiographic conditions, and the peculiarities of the genesis of the flora [Yurtsev, 2000].

The species composition of both the total flora of the specific territories, and its individual sections (western and eastern) of the Ketpen-Temerlik range, is dominated by the Magnoliophyta group, which accounts for 1860 species (98.4\%) and only a small number of species (30, or $1.6 \%)$ belong to Pinophyta, Polypodiophyta, Lycopodiophyta, and Equisetophyta (Figure 2). This ratio of groups is characteristic of the floras of mountainous Central Asia and the Holarctic as a whole [Camelin, 1973]. The ratio of monocotyledonous and dicotyledonous groups in the flora of the Ketpen-Temerlik ridge is approximately 1:5.4, i.e. Magnoliopsida (dicotyledonous plants) prevail over Liliopsida (monocotyledonous) by the species and genus composition by more than 5 times. The total number of monocotyledonous comprises 350 species or $18.4 \%$ of the total number; 


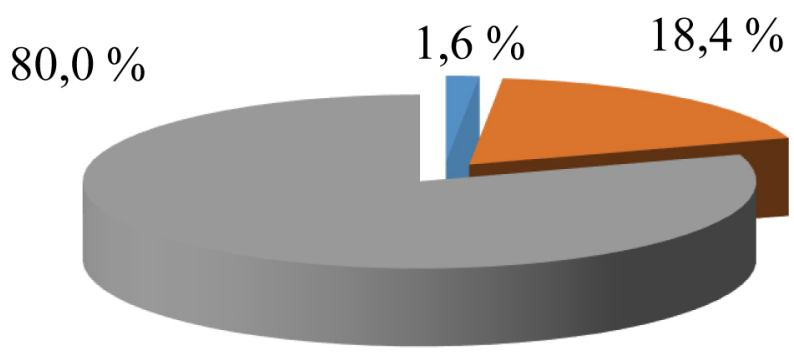

\section{Gymnosperms and ferns \\ - Monocotyledonous Dicotyledonous}

Figure 3. The overall composition of the flora of the Ketpen-Temerlik range

dicotyledonous plants include 1510 species or $80 \%$ (Figure 3).

This ratio of the number of species of monocotyledonous and dicotyledonous plants, according to R.V. Camelyn [1973], is characteristic of the flora of the eastern part of Ancient Middle-earth.

The average level of species richness of the flora families in the Ketpen-Temerlik range is 16 species, and the level of genus richness is 4.9. The above average level of species richness characterizes 22 families. The remaining 98 families include a combined total of $18.1 \%$ of all species. The average level of species richness of the genera is 3.1. On average, for each genus there are 3 species. Each family has 16 species.

One of the main characteristics of the flora is the flora spectra, expressing the features of systematic composition [Malyshev, 1972].

As can be seen from Table 1, in the flora of the Ketpen-Temerlik ridge, horsetails, ferns and gymnosperms are represented by the smallest number of species. The above-mentioned ratios of the main classes of vascular plants are characteristic of the entire flora of Ancient Middle Earth [Malyshev, 1972].

A comparative floristic spectrum of the flora of the Ketpen-Temerlik ridge is given by us according to the system of magnoliphytes of A.L. Tahtadzhyan [1987]. According to this system, the floristic spectrum of the flora of the
Ketpen-Temerlik range consists of 12 subclasses, where dicotyledonous Magnoliophyta are represented by 8 subclasses, covering $80 \%$; monocotyledonous Liliopsida consist of 4 subclasses, which make up $17.4 \%$ of the total species composition of the flora of the Ketpen-Temerlik range.

In general, the flora of the entire Ketpen-Temerlik range (in Kazakhstan and China) is represented by 120 families, 596 genera and 1890 species. This wealth of flora is associated with the position of the ridge, which facilitates the enrichment of species as a result of immigration from neighboring mountain systems, and, in part, with an increase in the number of plants due to the human activity.

The parameters of two specific floras are directly related to their size. Thus, in the western (Kazakhstan) part of the range, compared with the eastern (Chinese) part, the number of genera and species increases; the average size of the genus is larger; and the proportions of flora are close to the parameters of the Northern Tian Shan flora and mountainous Middle Asia. The increase in the species diversity in the studied flora is associated with an increase in the ecotopic diversity of the habitats vegetation in mountainous relief (Table 2).

The proportion of flora of the entire Ketpen-Temerlik range is 120:596:1890, or $1: 5: 15.7$. In the western part of the ridge, the

Table 1. Taxonomic diversity and proportions of the flora of the Ketpen-Temerlik range

\begin{tabular}{|l|c|c|c|}
\hline \multicolumn{1}{|c|}{ Name and area $\left(\mathrm{km}^{2}\right)$} & $\begin{array}{c}\text { The absolute number of } \\
\text { families: genera: species }\end{array}$ & $\begin{array}{c}\text { The proportions of flora family: } \\
\text { genus: species }\end{array}$ & $\begin{array}{c}\text { The average number of } \\
\text { species in a genus }\end{array}$ \\
\hline Ketpen-Temerlik, $20,925 \mathrm{~km}^{2}$ & $120: 596: 1890$ & $1: 5.0: 15.7$ & 3.1 \\
\hline Ketpen, $13,500 \mathrm{~km}^{2}$ & $111: 593: 1766$ & $1: 5.2: 15.7$ & 3.0 \\
\hline Temerlik, $7425 \mathrm{~km}^{2}$ & $117: 573: 1678$ & $1: 5.0: 14.3$ & 2.9 \\
\hline
\end{tabular}


Table 2. The degree of species richness of the flora of the Ketpen-Temerlik range

\begin{tabular}{|l|l|c|c|c|}
\hline \multicolumn{2}{|c|}{ Specification } & $\begin{array}{c}\text { Western part of the Ketpen- } \\
\text { Temerlik range }\end{array}$ & $\begin{array}{c}\text { Eastern part of the Ketpen-Temerlik } \\
\text { range }\end{array}$ & $\begin{array}{c}\text { Entire Ketpen-Temerlik } \\
\text { range }\end{array}$ \\
\hline \multicolumn{2}{|c|}{ Area $\left(\mathrm{km}^{2}\right)$} & 13500 & 7425 & 20925 \\
\hline \multirow{3}{*}{ Quantity } & Species & 1766 & 1678 & 1890 \\
\cline { 2 - 5 } & Genera & 593 & 573 & 596 \\
\cline { 2 - 5 } & Families & 111 & 117 & 120 \\
\hline \multicolumn{2}{|l|}{ Autonomy index } & -0.068 & -0.091 & -0.010 \\
\hline \multicolumn{2}{|l|}{ Genus coefficient } & 3.0 & 2.9 & 3.2 \\
\hline
\end{tabular}

proportion is 111:593:1766, and in the eastern part is $-117: 573: 1678$.

The demonstrated proportion shows us the degree of species and genus diversity characterizing the flora of the Ketpen-Temerlik range, which is quite rich for the flora of a mountainous region. In two specific territories of the Ketpen-Temerlik range, the systematic structure is distributed as follows: 1766 species belonging to 593 genera and 111 families were found in the western (Kazakhstan) part of the ridge, and 1678 species, 573 genera, and 117 families were identified in the eastern (Chinese) part (table 3). The western and eastern parts of the ridge have common flora consisting of 1423 species $(75.3 \%)$, i.e. more than half of all species growing on the entire KetpenTemerlik range, 250 species found in the eastern part of the range (Temerlik) do not grow in the western part of the Ketpen range. Similarly, 324 species growing on the western part of the ridge (Ketpen) are not found on the eastern part of the ridge (Temerlik). The use of the Jaccard coefficient [Jaccard, 1901] $(\mathrm{Kj}=0.425)$ for comparing the species composition of similar floras, for example in the western and eastern parts of the Ketpen-Temerlik range, shows us the deep similarity of the two specific floras and speaks of the floristic unity of the entire area, which is confirmed by having a common origin, and the history of the flora formation.

The analysis of the largest flora families of the Ketpen-Temerlik range allowed us to identify 28 of the largest families by the largest number of species (Table 3 ).

The largest is the Asteraceae family, containing 308 species, which accounts for $16.2 \%$ of the entire flora of the Ketpen-Temerlik ridge, and together with the families of Poaceae and Fabaceae, having 166 and 133 species, respectively, this already amounts to more than 607 species, i.e. on the three largest families account for $32.1 \%$ of the entire flora of the Ketpen-Temerlik ridge. The remaining 92 families account for only 263 species (15.4\%) and 131 genera (22.1\%). Such a composition of the leading families, sharply distinguished by the level of species richness, is typical for the flora of the Eastern part of the Ancient Mediterranean, but at the same time it has a number of features due to both ancient Mediterranean and boreal influence. In the traditional calculation

Table 3. The number of species in the largest families of the flora of the Ketpen-Temerlik range

\begin{tabular}{|c|c|c|c|c|c|c|}
\hline \multirow{2}{*}{ No. } & \multicolumn{2}{|c|}{ The Ketpen-Temerlik range } & \multicolumn{2}{|c|}{$\begin{array}{c}\text { West side of the } \\
\text { Ketpen-Temerlik range }\end{array}$} & \multicolumn{2}{|c|}{$\begin{array}{c}\text { East side of the } \\
\text { Ketpen-Temerlik range }\end{array}$} \\
\hline & Families & $\begin{array}{l}\text { Number of } \\
\text { species }\end{array}$ & Families & $\begin{array}{c}\text { Number of } \\
\text { species }\end{array}$ & Families & $\begin{array}{l}\text { Number of } \\
\text { species }\end{array}$ \\
\hline 1 & Asteraceae & 308 & Asteraceae & 272 & Asteraceae & 295 \\
\hline 2 & Poaceae & 166 & Poaceae & 156 & Poaceae & 160 \\
\hline 3 & Fabaceae & 133 & Fabaceae & 128 & Fabaceae & 110 \\
\hline 4 & Brassicaceae & 105 & Brassicaceae & 97 & Brassicaceae & 90 \\
\hline 5 & Caryophyllaceae & 93 & Rosaceae & 88 & Rosaceae & 78 \\
\hline 6 & Rosaceae & 90 & Caryophyllaceae & 82 & Caryophyllaceae & 71 \\
\hline 7 & Lamiaceae & 81 & Chenopodiaceae & 69 & Lamiaceae & 69 \\
\hline 8 & Chenopodiaceae & 75 & Lamiaceae & 66 & Ranunculaceae & 58 \\
\hline 9 & Ranunculaceae & 74 & Ranunculaceae & 60 & Chenopodiaceae & 56 \\
\hline $10-11$ & Scrophulariaceae & 57 & Scrophulariaceae & 54 & Scrophulariaceae & 52 \\
\hline $10-11$ & Cyperaceae & 53 & Cyperaceae & 52 & Cyperaceae & 52 \\
\hline Total & & 1235 & & 1124 & & 1091 \\
\hline
\end{tabular}


used in the flora analysis, 10 large families account for more than half $(62.5 \%)$ of the entire flora of the Ketpen-Temerlik ridge. Similar correlations are observed in the Tian Shan flora and, apparently, are characteristic of all flora of mountainous Middle Asia. A comparison of the flora of the western and eastern parts of the Ketpen-Temerlik ridge with the entire studied flora (the ratio of the 10 leading families) using Spearman's rank correlation coefficient [Chang et al., 2012] (at a 5 percent significance level) showed the reliability of the analyzed parameters, as in the case of the 10 leading genera (Table 6).

In the studied territories of the western and eastern parts of the Ketpen-Temerlik range, the western part dominates when comparing the largest families as a percentage of the number of species characteristic of a particular territory (Figure 4).

The first place in the number of species belongs to the Asteraceae family - 308 species, which play a large floristic role in the arid regions of Middle Asia and the Arctic. In second place is the Poaceae family - 166 species, whose role is also sharply enhanced under extreme conditions of existence [Malyshev, 1969]. The Fabaceae family is third, due to the polymorphic genera Astragalus and Oxytropis, which are the largest

Table 4. Spearman's rank correlation coefficient [Sp] [Spearman, 1904] at the level of dominant families (A) and genera (B)

\begin{tabular}{|l|c|c|c|}
\hline \multicolumn{2}{|c|}{ Specification } & $\begin{array}{c}\text { West side of the } \\
\text { Ketpen-Temerlik } \\
\text { range }\end{array}$ & $\begin{array}{c}\text { East side of the } \\
\text { Ketpen-Temerlik } \\
\text { range }\end{array}$ \\
\hline $\begin{array}{l}\text { Ketpen- } \\
\text { Temerlik } \\
\text { range }\end{array}$ & A & 0.97 & 0.97 \\
\cline { 2 - 4 } & B & 0.58 & 0.94 \\
\hline
\end{tabular}

genera of the flora of Middle Asia, with 133 species or $7.1 \%$. The leading positions are also occupied by other families, which are characteristic of Ancient Central Asia: Brassicaceae (105 species), Caryophyllaceae (93 species), Lamiaceae (81 species), and Apiaceae (50 species). In the Rosaceae family (90 species), which is in sixth place, the Potentilla genus is characterized by the highest concentration of species. In eighth place is the Chenopodiaceae family ( 76 species) and its importance increases sharply in the desert areas of Turan. A significant number of species are represented by the families: Ranunculaceae (74 species), Scrophulariaceae (57 species), Boraginaceae (46 species), and Polygonaceae (40 species).

The representatives of these families are found everywhere on the Ketpen-Temerlik Ridge. The high position of the Ranunculaceae and Cyperaceae families is noteworthy, showing some boreal feature of the studied flora. The specific features of the flora of the Ketpen-Temerlik ridge are emphasized by the richness of species of families:Alliaceae, Liliaceae, Rubiaceae. These families are richly represented in Middle Asia and Afghanistan [Kamelin, 1973]. Additionally, the Primulaceae, Gentianaceae, and Salicaceae families are of great importance in the flora of the Ketpen-Temerlik range. The presence in the studied flora of a large number of one and two-species families is a feature inherent in the floras that develop under extreme conditions. The range of average families (from 6 to 10 species) accounts for 117 species ( $18.3 \%$ of the total). For the entire Ketpen-Temerlik range, there are 16 such families; in the western part of the Ketpen-Temerlik range - 14 families, in the eastern part - 15 families. In the study area, in 32 oligotypic families, 100 species were registered (21.6\%). There are 32 such families in the flora of the western part

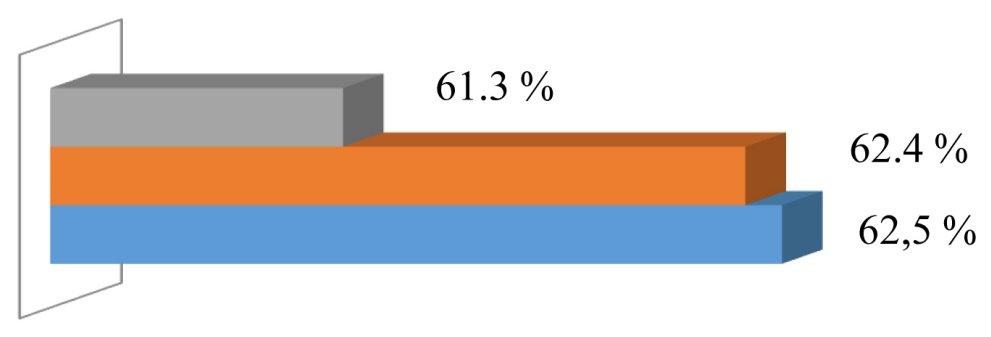

\footnotetext{
Eastern part of the Ketpen-Temerlik ridge

Western part of the Ketpen-Temerlik ridge

- Whole Ketpen-Temerlik ridge
}

Figure 4. Distribution of the ten leading flora families of the Ketpen-Temerlik range 
of the Ketpen-Temerlik range, and 27 families in the eastern part. There are 42 monotypic families in the flora of the Ketpen-Temerlik ridge, which makes up $35 \%$ of the total number of species.

It should be noted that according to the location of the dominant families, i.e. Asteraceae, Poaceae, Fabaceae and Brassicaceae, the flora of the Ketpen-Temerlik ridge occupies an intermediate position between Western and Central Asia, and the presence of such large and characteristic boreal families as Caryophyllaceae, Ranunculaceae, Rosaceae, Cyperaceae indicates its connection with the northern, boreal and mesophilic flora of Eurasia, which could penetrate the Ketpen-Temerlik ridge from the north through the Dzungar Alatau, Altai and Sayan mountains in the ice age.

One of the most important stages of understanding the specificity of the studied flora is comparing it with other similar floras. The result of this comparison enables to judge the florogenetic originality and current trends in the dynamics of flora more objectively. The main purpose of the comparative study of flora is to identify their originality and botanical and geographical specificity, which, according to L. V. Malyshev, helps to identify the physiognomy of the flora not as a mechanical set of species, but as a naturally formed complex [Malyshev, 1969]. In this regard, comparing the richness of various mountain flora of Kazakhstan as a whole is of considerable interest.
The spectrum of the leading families of the Ketpen-Temerlik range corresponds and is close to the spectrum of the Northern Tian Shan (Table 5). The authors were interested to find out how rich the flora of the Ketpen-Temerlik ridge is in comparison with the floras of other mountain regions of Kazakhstan. A comparative analysis of the flora of the Ketpen-Temerlik ridge with 4 flora of mountainous territories: the Central Kazakh small-hills, Dzhungar Alatau, Tarbagatai and Kungei Alatau was carried out. The vast territory of the Central Kazakh Small-hills, according to literary sources, has 1,453 species [Karmysheva and Rachkovskaya, 1973]. The flora of the Dzungar Alatau contains 2168 species [Goloskokov, 1984]. The flora of the eastern part of the Kungey Alatau range is represented by 1662 species [Mukhtubaeva, 2000]. The flora of the Tarbagatai Mountains consists of 1640 species [Stepanova, 1962].

When comparing the floristic spectra of the leading families of the Ketpen-Temerlik ridge, and the located northern of the Dzhungar Alatau, it turned out that the first four largest families are distributed equally; the family Rosaceae (4.9\%) moved to 5th place in the flora of the Dzungar Alatau, which is in the 6th place in the flora of the Ketpen-Temerlik ridge; further in the flora of the Dzungar Alatau on the families of Caryophyllaceae $(4.5 \%)$ and Lamiaceae $(4.2 \%)$ are on the

Table 5.Spectrum of the leading families of the Northern Tian Shan [Baitenov, 1985; Rubtsov, 1953] and the Ketpen-Temerlik range

\begin{tabular}{|c|c|c|c|c|c|}
\hline No. & Families & $\begin{array}{l}\text { Northern } \\
\text { Tien-Shan }\end{array}$ & No. & Families & Ketpen-Temerlik range \\
\hline 1. & Asteraceae & 254 & 1. & Asteraceae & 308 \\
\hline 2. & Fabaceae & 232 & 2. & Poaceae & 166 \\
\hline 3. & Poaceae & 211 & 3. & Fabaceae & 133 \\
\hline 4. & Brassicaceae & 140 & 4. & Brassicaceae & 105 \\
\hline 5. & Chenopodiaceae & 112 & 5. & Caryophyllaceae & 93 \\
\hline 6. & Rosaceae & 101 & 6. & Rosaceae & 90 \\
\hline 7. & Ranunculaceae & 99 & 7. & Lamiaceae & 81 \\
\hline 8. & Liliaceae & 92 & 8. & Chenopodiaceae & 75 \\
\hline 9. & Caryophyllaceae & 84 & 9. & Ranunculaceae & 74 \\
\hline 10. & Apiaceae & 84 & 10. & Scrophulariaceae & 57 \\
\hline 11. & Cyperaceae & 78 & 11. & Cyperaceae & 53 \\
\hline 12. & Lamiaceae & 59 & 12. & Apiaceae & 50 \\
\hline 13. & Scrophulariaceae & 55 & 13. & Boraginaceae & 46 \\
\hline 14. & Boraginaceae & 48 & 14. & Polygonaceae & 40 \\
\hline 15. & Polygonaceae & 37 & 15. & Liliaceae & 29 \\
\hline
\end{tabular}


6th and 7th places; the families Ranunculaceae $(3.6 \%)$ and Scrophulariaceae (3.6\%) are on the 8th and 9th places;in 10th place is the Chenopodiaceae family $(2.6 \%)$, which is in 8 th place in the flora of the Ketpen-Temerlik ridge; in the 9th place is occupied by the Ranunculaceae family, and on the last place in the flora of the KetpenTemerlik ridge is the Scrophulariaceae family (3.1\%) (table 6). In the Tarbagatai flora, the first four families: Asteraceae, Poaceae, Fabaceae and Brassicaceae, also occupy a leading position; the 5 th and 6th places were moved by the families Rosaceae (5.8\%) and Ranunculaceae (4.8\%), which are in the 6th and 8th place in the flora of the Ketpen-Temerlik ridge; the Caryophyllaceae (4.4\%) and Lamiaceae (3.7\%) families moved to 7th and 8th place, which are in the 5th and 7th places in the flora of the Ketpen-Temerlik ridge (Table 6).

In the flora of the Central Kazakh Smallhills, the first four places are occupied by the families: Asteraceae, Poaceae, Fabaceae and Brasicaceae; the Chenopodiaceae family moved to 5 th place $(6.0 \%)$; in 6th place is the Rosaceae family (4.5\%); at 7, 8 and 9th places are the Caryophyllaceae (4.2\%), Ranunculaceae (4.2\%) and Scrophulariaceae $(4.0 \%)$ families, which are at 5, 8 and 9th places in the flora of the KetpenTemerlik ridge, and finally, the last 10th place is occupied by the Lamiaceae family (2.9\%), standing in the 7th place in the flora of the KetpenTemerlik ridge. In the flora of the eastern part of Kungei Alatau, the first four families have the same sequential arrangement as in the flora of the Ketpen-Temerlik ridge. The Rosaceae (4.6\%) and Lamiaceae (4.2\%) families, located in the flora of the Ketpen-Temerlik ridge in 6 th and 7 th places, moved to 5 th and 6th place; 7 and 8 places are occupied by the Caryophyllaceae (4.1\%) and
Chenopodiaceae $(4.0 \%)$ families, standing in the flora of the Ketpen-Temerlik ridge in 5 and 8th place; and the last places belong to the Ranunculaceae (3.8\%) and Scrophulariaceae $(4.0 \%)$ families.

Thus, the analysis of the flora showed a significant affinity of the Ketpen-Temerlik ridge flora and the flora of the eastern part of Kungei Alatau; the flora of the Central Kazakh Shoal and Dzhungar Alatau are also close to the flora of the Ketpen-Temerlik ridge, the most distant flora from the flora of the Ketpen-Temerlik ridge is the flora of the Tarbagatai ridge. Similar results were obtained when comparing the richness of mountain flora with genera and families. The ratio of the number of species in the flora can serve as an indicator of the autochthonous and allochthonous tendencies in the development of the flora (Table 7).

It is known that the larger the average number of species in a genus, the more pronounced the autochthonous processes are in the formation of flora, and the lower the average, the greater the role that species migration plays in the process of florogenesis [Baitenov, 1985]. On the basis of the quantitative characteristics, it is clear that the autochthonous trends are better developed in the formation of the flora of the Tarbagatai ridge, the Dzungar Alatau, and the Central Kazakh smallhills. An insignificant manifestation of the autochthonous processes is observed in the floras of the eastern part of the Kungey Alatau and the Ketpen-Temerlik range.

L.I. Malyshev [Malyshev, 1972] proved that the ratio of the number of species and the number of genera is determined by a curvilinear dependence. He proposed an indicator that would allow for assessing the ratio of the autochthonous and allochthonous tendencies in the process of

Table 6. Spectrum of the leading families of the Ketpen-Temerlik range and neighboring territories

\begin{tabular}{|c|l|c|c|c|c|c|}
\hline No. & \multicolumn{1}{|c|}{ Families } & $\begin{array}{c}\text { Dzungar Alatau } \\
\text { ridge }\end{array}$ & $\begin{array}{c}\text { Tarbagatai } \\
\text { ridge }\end{array}$ & $\begin{array}{c}\text { The Central Kazakh } \\
\text { small-hills }\end{array}$ & $\begin{array}{c}\text { Kungey } \\
\text { Alatau ridge }\end{array}$ & Ketpen-Temerlik ridge \\
\hline 1. & Asteraceae & 16,2 & 13,1 & 13,5 & 16,0 & 16,2 \\
\hline 2. & Poaceae & 9,8 & 9,7 & 7,0 & 9,0 & 8,7 \\
\hline 3. & Fabaceae & 7,0 & 8,2 & 7,9 & 7,7 & 7,0 \\
\hline 4. & Brassicaceae & 6,1 & 6,2 & 6,2 & 6,3 & 5,5 \\
\hline 5. & Caryophyllaceae & 4,5 & 4,4 & 4,2 & 4,1 & 4,9 \\
\hline 6. & Rosaceae & 4,9 & 5,8 & 4,5 & 4,6 & 4,7 \\
\hline 7. & Lamiaceae & 4,2 & 3,7 & 2,9 & 4,2 & 4,4 \\
\hline 8. & Chenopodiaceae & 2,6 & 3,2 & 6,0 & 4,0 & 4,0 \\
\hline 9. & Ranunculaceae & 3,6 & 4,8 & 4,2 & 3,8 & 3,9 \\
\hline 10 & Scrophulariaceae & 3,6 & 4,5 & 4,0 & 4,0 & 3,1 \\
\hline
\end{tabular}


florogenesis. The autonomy index of flora (A) is the relative difference between the actual $(\mathrm{S})$ and estimated $(\hat{\mathrm{S}})$ number of species:

$$
A=\frac{S-\hat{S}}{S}
$$

In this case, the estimated number of species is determined by the empirical quadratic equation:

$$
\hat{\mathrm{S}}=314.1+0.0045383 \mathrm{G}^{2}
$$

where: $G$ is the number of genera in the flora.

A positive value of the index of autonomy indicates the predominance of the autochthonous tendencies in the development of flora, whereas a negative value - the predominance of the allochthonous tendencies, and a zero value indicates the balance of these tendencies. Our calculations show that the positive values of the autonomy indicator are characteristic of the flora of Tarbagatai, Dzhungarsky Alatau and the Central Kazakh Small hills. This may indicate that these territories are the locations of powerful mountain florogenesis. The negative values of the autonomy index of the flora of the Ketpen-Temerlik range indicate the predominance of the allochthonous tendency in the formation of its flora. In the eastern part of the Kungey Alatau, the autonomy index is almost close to zero, which indicates a balance of the autochthonous and allochthonous tendencies.

An understanding of the degree of similarity of the flora of the studied region with adjacent regions is provided through a mathematical method, in particular the Spearman's rank correlation coefficient [Malyshev, 1969], which is calculated by the following formula:

$$
\begin{aligned}
& \text { Ps }=1-6 \Sigma \mathrm{d}^{2}, \\
& \mathrm{n}^{3}-\mathrm{n}
\end{aligned}
$$

where: $\Sigma \mathrm{d}^{2}$ is the sum of squared differences $(\mathrm{d}=\mathrm{x}-\mathrm{y})$ between the corresponding ranks ( $\mathrm{x}$ and $\mathrm{y}$ ) of two rows; $\mathrm{n}$ is the number of pairs of ranks.
In this case, both coefficients vary from +1 (complete similarity of two rows) to -1 (complete dissimilarity, opposite order of taxa), but have different scales, i.e. not adequate to each other in terms of expression of similarity (Table 8).

From Table 8, it can determined that the flora of the Ketpen-Temerlik range has a significant similarity to the flora of the Dzungar Alatau (rank correlation coefficient: +0.98 ) and Eastern part of the Kungey Alatau (rank correlation: +0.95). This correlation indicator is somewhat less for the flora of the Central Kazakh small-hills and Tarbagatai range: +0.74 and +0.88 , respectively. This data reflects the natural reality in which the Ketpen-Temerlik range flora is much closer in composition that of the Dzungar Alatau, the Eastern part of Kungey Alatau, and even to the flora of the Tarbagatai mountains. There are significant differences with the flora of the Central Kazakh Uplands, which is significantly different in climatic and orographic conditions.

The analysis of the species richness pertaining to the genera of the Ketpen-Temerlik ridge flora showed the following: of 593 genera, 25 genera are large (containing 10 or more species). on the 24 leading genera of flora in the western part of the Ketpen-Temerlik ridge account for $29.8 \%$, and in the eastern part, respectively, accounts for $30.8 \%$. it should be noted that the 25 largest genera of flora of the entire Ketpen-Temerlik ridge contain 588 species, or $31.1 \%$ of the total flora. The bulk of these genera falls on the large families. Each genus has an average of 3.2 species. In the traditional calculation of the largest genera, 10 large genera account for slightly more than half of the composition (16.4\%) of the entire flora of the Ketpen-Temerlik ridge (Figure 5).

On the Ketpen-Temerlik range, the features of the floras in the eastern part of ancient Cen-

\begin{tabular}{|c|c|c|c|c|c|}
\hline Regions & $\begin{array}{l}\text { Number of } \\
\text { species }\end{array}$ & $\begin{array}{l}\text { Number of } \\
\text { genera }\end{array}$ & $\begin{array}{l}\text { Number of } \\
\text { families }\end{array}$ & $\begin{array}{c}\text { The average number of } \\
\text { species in a genus }\end{array}$ & Autonomy index \\
\hline Ketpen-Temerlik Range & 1890 & 593 & 120 & 3.18 & -0.010 \\
\hline Dzungar Alatau & 2168 & 622 & 112 & 3.48 & +0.046 \\
\hline $\begin{array}{l}\text { Eastern part of the Kungey } \\
\text { Alatau }\end{array}$ & 1662 & 547 & 99 & 3.03 & -0.0060 \\
\hline Tarbagatai range & 1640 & 492 & 80 & 3.33 & +0.142 \\
\hline The Central Kazakh small-hills & 1453 & 480 & 88 & 3.02 & +0.065 \\
\hline
\end{tabular}
tral Asia manifest themselves in the species richness of the Gagea, Erigeron, Caragana, Galium,

Table 7. Quantitative characteristics of some mountain floras of Kazakhstan 
Table 8. Ratio of ranks in the family spectra of the flora of the Ketpen-Temerlik range and neighboring regions

\begin{tabular}{|l|c|c|c|c|c|}
\hline \multicolumn{1}{|c|}{ Families } & $\begin{array}{c}\text { Ketpen-Temerlik } \\
\text { range }\end{array}$ & $\begin{array}{c}\text { Dzungar Alatau } \\
\text { range }\end{array}$ & $\begin{array}{c}\text { Eastern part of the } \\
\text { Kungey Alatau range }\end{array}$ & $\begin{array}{c}\text { The Central } \\
\text { Kazakh small- } \\
\text { hills }\end{array}$ & $\begin{array}{c}\text { Tarbagatai } \\
\text { range }\end{array}$ \\
\hline Asteraceae & 1 & 1 & 1 & 1 & 1 \\
\hline Poaceae & 2 & 2 & 2 & 2 & 2 \\
\hline Fabaceae & 3 & 3 & 3 & 3 & 3 \\
\hline Brassicaceae & 4 & 4 & 4 & 4 & 4 \\
\hline Caryophyllaceae & 5 & 6 & 6 & 8 & 7 \\
\hline Rosaceae & 6 & 5 & 7 & 6 & 5 \\
\hline Lamiaceae & 7 & 7 & 5 & 10 & 8 \\
\hline Chenopodiaceae & 8 & 10 & 8 & 5 & - \\
\hline Ranunculaceae & 9 & $9-10$ & 10 & 7 & - \\
\hline Scrophulariaceae & 10 & 0.98 & 0.95 & $\mathbf{0 . 7 4}$ & $\mathbf{0 . 8 8}$ \\
\hline $\begin{array}{l}\text { Coefficient } \\
\text { rank correlation } \\
\text { by Spearman }\end{array}$ & & & & & \\
\hline
\end{tabular}

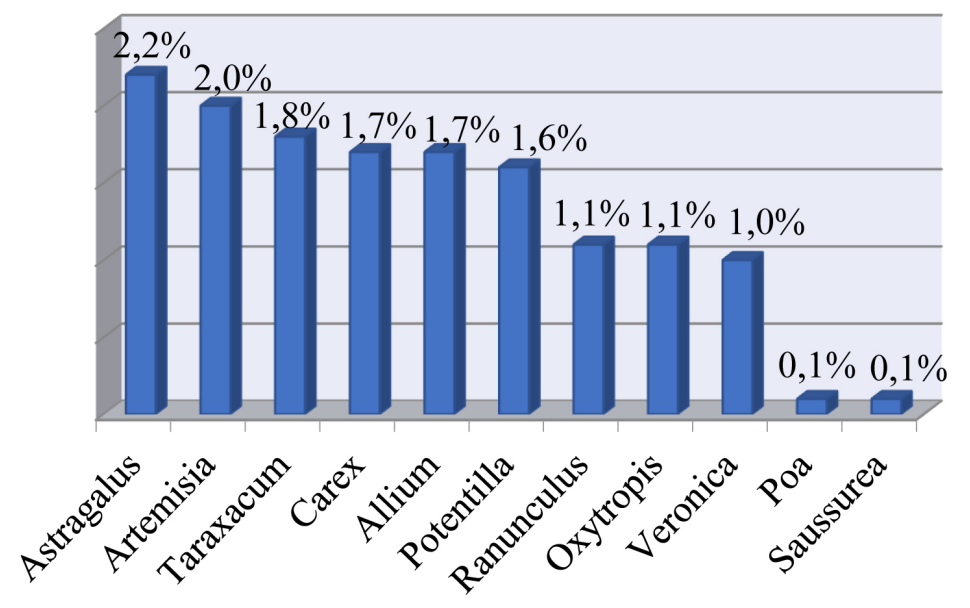

Figure 5. The ratio of the leadinggenerain the flora of the Ketpen-Temerlik ridge

Silene, Euphorbia, Lappula, and other genera. The polymorphism of the genera Potentilla, Poa, Ranunculus, Vicia, Silene reflects the diversity of place habitat conditions on the Ketpen-Temerlik ridge. A significant number of species in the polymorphic Polygonum, Veronica, and Galium genera is the result of a large number of annual species that are easily distributed with the field crop in their composition. Attention is drawn to the significant polymorphism of the Oxytropis, Draba, Erigeron, Elymus, Scorzonera, Dracocephalum genera, indicating different ways of enriching the flora of the Ketpen-Temerlik range. Among the polymorphic genera of the KetpenTemerlik range's flora, only the Euphorbia and Geranium do not belong to particularly polymorphic genera. The remaining major genera belong to families with the richest species. Their role in their respective families is different. Thus, the $\mathrm{Fa}$ baceae Lindl. family is represented in the flora of the Ketpen-Temerlik range by the largest Astragalus L. and Oxytropis L. genera. A similar concentration of species in individual genera of the studied flora exists in the Saussurea, Erigeron, Scorzonera genera which belong to the polymorphic, but their role in the family is much smaller. The Poaceae family, contains the polymorphic genera: Poa, Stipa, Festuca; the Brassicaceae family includes one polymorphic genus - Draba L.; the Cyperaceae family includes one polymorphic genus the Carex L.; in the Lamiaceae family includes genus Dracocephalum, which is not related to particularly polymorphic genera. In the Scrophulariaceae family, this is the Pedicularis L. genus. In the Rosaceae, Liliaceae, Polygonaceae, Rubiaceae families, the role of the largest genera is especially great.

The majority of species in the flora of the Ketpen-Temerlik range belong to the genera with a relatively small number of species (Figure 6). 


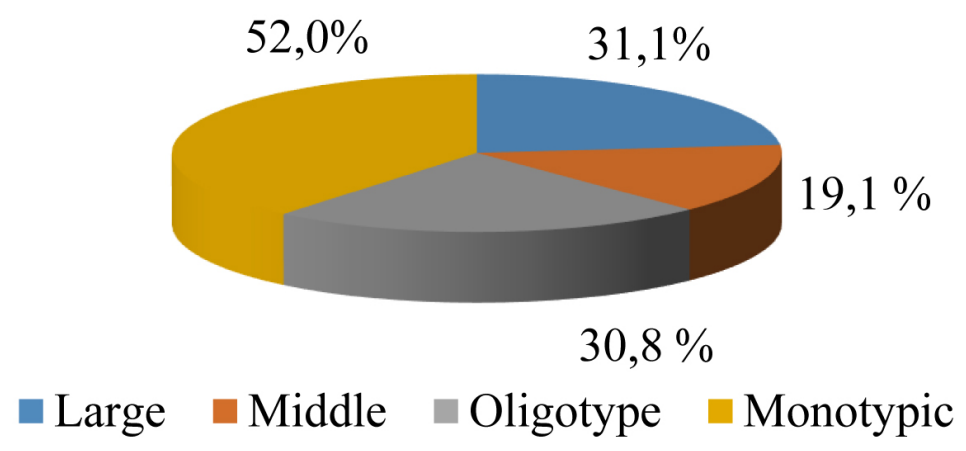

Figure 6. Ratio of large, medium, small and single-species genera of the floraof the Ketpen-Temerlik range

The average genera (from 6 to 9 species) consist of 51 species. Combined, this represents 361 species $(19.1 \%)$. There are 11 genera containing 9 species each: Dianthus, Cerastium, Salsola, Rumex, Androsace, Cotoneaster, Zygophyllum, Pyrethrum, Tragopogon, Festuca, Tulipa; 8 species each contain 9 genera: Senecio, Ligularia, Lagochilus, Seseli, Hedysarum, Erysimum, Viola, Erysimum, Geranium; 7 species each contain 10 genera: Puccinella, Centaurea, Crepis, Plantago, Phlomoides, Thalictrum, Minuartia, Aconitum, Chenopodium, Cuscuta; 6 species contains 21 genera. In the 203 oligotype genera account for 565 species (30.8\%), of which 5 species each contain 20 genera, 4 species contain 27 genera, 3 species contain 45 genera, and 2 species contain 111 genera. There are 307 monotypic genera in the flora of the Ketpen-Temerlik ridge, which is $52.0 \%$ of the number of genera and $28.8 \%$ of the number of species. As can be seen from the review of the leading families and genera presented above, in general terms, the flora of the Ketpen-Temerlik ridge corresponds to the flora of the eastern part of Ancient Middle-earth, and in particular mountainous Middle Asia. The leading role of the Asteraceae, Poaceae, Fabaceae, Brassicaceae families is characteristic of the Holarctic flora, and their role is enhanced in the arid regions of Middle Asia, and the predominance of the Chenopodiaceae, Lamiaceae, Apiaceae families indicates the influence of the desert territories of Turan and Western Asia.

\section{CONCLUSION}

The Ketpen-Temerlik range, as an integral mountain system has practically not been studied floristically. A comprehensive analysis of the flora of the western (Kazakhstan) and eastern
(Chinese) parts of the ridge was conducted. The study showed that the flora of the Ketpen-Temerlik range is heterogeneous as a result of the impact of various floristic centers, the different ages of the formation of its individual taxa, as well as the influence of the deserts of Central Asia (China, Mongolia, Tibet). The flora of the Ketpen-Temerlik range includes 1890 species, which make up $63.0 \%$ of the flora of the entire Northern Tian Shan. Angiosperms make up almost $98.4 \%$ of the ridge flora, $80.0 \%$ of which are dicotyledonous and $18.5 \%$ are monocotyledonous. The systematic structure of the two specific territories of the Ketpen-Termerlik range is distributed as follows: 1747 species belonging to 585 genera and 111 families were identified in the western part of the ridge, and 1673 species, 577 genera and 117 families in the eastern part. The western and eastern parts of the range share 1423 species, or $75.3 \%$ of all species growing on both parts of the KetpenTemerlik range. A review of leading families and genera showed that, in general terms, the flora of the Ketpen-Temerlik ridge corresponds to the flora of the eastern part of Ancient Middle Earth, in particular, mountainous Middle Asia. The leading role of the Asteraceae, Poaceae, Fabaceae, and Brassicaceae families is characteristic of the Holarctic flora, their role is increasing in the arid regions of Central Asia. The advantage of the Chenopodiaceae, Lamiaceae, and Apiaceae families indicates the influence of the desert territories of Turan and Western Asia (Western Asia, Southwest Asia). The most numerous families in the studied area are the following: Asteraceae (308 species), Poaceae (166), Fabaceae (133), Brassicaceae (105), Caryophyllaceae (93), Rosaceae (90), Lamiaceae (81), Chenopodiaceae (75), Ranunculaceae (74), Scrophulariaceae (57). More specifically, the ratio of flora can be judged by the generic spectra of flora. The major genera of 
the studied area are: Astragalus (43 species), Artemisia (38), Taraxacum (34) Carex (33) Allium (33), Potentilla (31), Ranunculus (22), Oxytropis (21), Veronica (20), Poa (18), Saussurea (18). In general, the flora of the Ketpen-Temerlik range is a mountain-steppe, with a large participation of boreal high-mountain and mid-mountain meadows, meadow-steppes and xerophytic desertsteppe and desert species of plants.

\section{REFERENCES}

1. Flora of the USSR. Volumes 1-30. 1934-1964. Moscow-Leningrad.

2. Flora of China. 1994, 2003.

3. Cherepanov S. K. 1995. Vascular plants of Russia and neighboring States (within the former USSR). St. Petersburg.

4. Abdulina S. A. 1998. Vascular plants of Kazakhstan. Almaty.

5. Rubtsov N. I. 1948. Relict Sands in the mountains of the Northern Tien Shan. Vestnik of KazSSR, 4(37), 76-79. (in Rissian).

6. Baitenov M. S. 1985. Alpine flora of the Northern Tien Shan. Alma-Ata.

7. Bykov B. A. 1979. On the quantitative assessment of endemism. Botanical Materials of the Herbarium Of the Institute of botany of The Kazakh SSR, 11, 3-8.

8. Rubtsov N. I. 1964. On the generic endemism of flora of Central Asia. In: Botanical Materials of the herbarium of the Institute of botany. Alma-Ata, 2, 3-12.

9. Chupakhin V.M. 1970. Natural zoning of Kazakhstan. Alma-Ata.

10. Atlas of the Kazakh SSR.Natural conditions and resources. 1982. Moscow: Main Directorate of Geodesy and Cartography under the USSR Council of Ministers, 1, 81 .

11. Pavlov N. V. 1959. Endemic and relict plants of Kazakhstan. Botany in Kazakhstan. Alma-Ata, 19-28.

12. Yurtsev B.A. 2000. Some prospects for the development of comparative floristics at the turn of the XX - XXI centuries. Comparative floristics at the turn of the III millennium: achievements, problems and prospects. St. Petersburg, 12-19.

13. Malyshev L. V. 1972. Floristic Spectra of the Soviet Union. History of the flora and vegetation of Eurasia. Leningrad, 17-40.

14. Gellie, N. J. H. 2005. Native vegetation of the Southern Forests: South-east Highlands, Australian Alps, South-west Slopes and SE Corner bioregions. Cunninghamia, 9, 219-253.
15. Moreno J., Terrones A., Juan A., et al. 2018. Halophytic plant community patterns in Mediterranean saltmarshes: shedding light on the connection between abiotic factors and the distribution of halophytes. Plant and Soil, 430(1-2), 185-204.

16. Chen B. M, Wang G. X., Peng S. L. 2009. Role of desert annuals in nutrient flow in arid area of Northwestern China: a nutrient reservoir and provider. Plant Ecology, 201(2): 401-409.

17. Chang Z. F, Zhu S. J, Han F. G, et al. 2012. Differences in response of desert plants of different ecotypes to climate warming: a case study in Minqin, Northwest China. Journal of Arid Land, 4(2), 140-150.

18. Kamelin R. V. 1973. Florogenetic analysis of the natural flora of mountainous Central Asia. Leningrad.

19. Malyshev L. V. 1972. Quantitative assessment of the flora of Putorana. Flora Putorana. Novosibirsk, 163-186.

20. Tahtajyan A. L. 1987. Magnoliophyte system. Moscow.

21. Jaccard P. 1901. Distribution de la flore alpine dans le Bassin des Dranses et dans quelques regions voisines. Bull. Soc. Vaudoise sci. Natur., 37(140), 241-272.

22. Spearman C. 1904. The proof between the two things. American Journal of Psychology. 15(1), 72-101.

23. Malyshev L. V. 1969. Dependence of floristic wealth on external conditions and historical factors. Botanical Journal, 54, 1137-1147.

24. Karmysheva Z. V., Rachkovskaya E. I. 1973. Botanical geography of the steppe part of Central Kazakhstan. Leningrad.

25. Goloskokov V. P. 1984. Flora Dzhungarskiy Alatau. Alma-Ata.

26. Mukhtubaeva, S. K. 2000. Flora of the Eastern Part of the Kungey Alatau range. Ph.D. Thesis. AlmaAta: National Academy of Science Kazakhstan Republic.

27. Stepanova E. F. 1962. Vegetation and flora of the Tarbagatai range. Alma-Ata.

28. Rubtsov N. I. 1953. North Tien-Shan geobotanical province and its plant resources. Ph.D. Thesis. Leningrad: National Academy of Science.

29. Illustrated determinant of plants in Kazakhstan. Volumes 1-2. 1962-1975. Alma-Ata.

30. Flora Xinjiangensis. 1992-2004. Volumes 1-6. Urumchi.

31. Flora of Kazakhstan. Volumes 1-9. 1956-1966. Alma-Ata.

32. Plants of Central Asia. Volumes 1-9. 1963-1989. Moscow-Leningrad.

33. Determinant of plants of Central Asia. Volumes 1-10. 1968-1993. Tashkent. 